\title{
Okula Hazır Oluş ve Yürütücü İşlev Performansları Arasındaki İlişki*
}

\section{The Relationship between School Readiness and Executive Function Performances}

\begin{abstract}
Asiye İvrendi ${ }^{1}$
Makale Geçmişi

Geliş : 26 Aralık 2019

Düzeltme : 26 Mavis 2020

Kabul : 1 Eylül 2020

\section{Makale Türü}

Arastirma Makalesi

Article History

Received : 26 December 2019

Revised : 26 May 2020

Accepted : 1 September 2020

Article Type

Research Article

Öz: Bu çalışmada, 5-6 yaş çocuklarının okula hazır oluș düzeyleri ile yürütücü işlev görevlerinde sergiledikleri performansları arasındaki ilişki incelenmiştir. İlişkisel tarama yönteminin kullanıldığı bu çalışmanın örneklemini 69 çocuk oluşturmuştur. Çocukların matematik, fen, ses, çizgi ve labirent alt boyutlarının ölçülmesiyle okula hazır oluş düzeyleri belirlenmiştir. Yürütücü işlev performanslarını belirlemek amacıyla çalışma belleği ve engelleyici kontrol becerilerine yönelik olan görevler kullanılmıştır. Veriler, Kendall's tau-b korelasyon tekniği ve Mann Whitney U testi kullanılarak analiz edilmiştir. Bulgular, çocukların çizgi alt boyutu puanlarının engelleyici kontrol görevi ile; çizgi, matematik, ve labirent alt boyutu puanlarının çalışma belleği görevi ile ve fen, ses ve labirent puanlarının ise hem çalışma belleği hem de engelleyici kontrol performansını içeren görev ile ilişkili olduğunu göstermektedir. Çalışma belleği performansları yüksek olan çocukların matematik, çizgi ve labirent alt boyutu puanlarının, hem çalışma belleği hem de engelleyici kontrol performansları yüksek olan çocukların ise fen, ses ve labirent alt boyutlarından aldıkları puanlarının yüksek olduğu belirlenmiştir.

Anahtar Kelimeler: Okula hazır oluş, Yürütücü işlevler, Çalışma belleği, Engelleyici kontrol

Abstract: In this study, the relationship between the 5- and 6-year-old children's school readiness levels and executive function performances was examined using a relational survey design. The sample of this study comprised 69 children. Children's level of school readiness was determined by measuring the subdimensions of mathematics, science, sound, drawing, and labyrinth. To determine the executive function performances, tasks measuring $\mathrm{w}$ orking memory and inhibitory control were used. The data were analyzed using the Kendall's tau-b correlation technique and Mann-Whitney $U$ test. The results show that children's mathematics, drawing and labyrinth scores were related with working memory performances. Science, sound and labyrinth scores were associated with both working memory and inhibitory control tasks. Children whose working memory scores were high were found to score high on the mathematics, drawing and labyrinth sub-dimensions. In addition, children whose scores were higher on working memory and inhibitory control tasks had high scores on the sub-dimensions of science, sound and labyrinth.
\end{abstract}

Keywords: School readiness, Executive functions, Working memory, Inhibitory control

\footnotetext{
* Bu çalışmanın bir kısmı 6. Uluslararası Okul Öncesi Eğitim Kongresinde “sözlü bildiri” olarak sunulmuş ve özeti kongre kitabında yayınlanmıştır. 1Pamukkale Üniversitesi, Eğitim Fakültesi, Temel Eğitim Bölümü, Okul Öncesi Eğitimi Anabilim Dalı, aivrendi@pau.edu.tr, ORCID: 0000-00020555-9247.
} 


\section{SUMMARY}

\section{Introduction}

School readiness is defined as being ready for learning (Oktay, 2013). In another definition, school readiness focuses on children's state of development and learning in health-physical development, social-emotional development, approach to learning, language development and cognitive-general knowledge (Maxwell et al., 2001). Studies investigating the factors affecting children's school readiness have focused on different variables. According to Oktay (1983), factors affecting children's readiness for primary school are generally physiological, cognitive, environmental and emotional. Whether children receive preschool education, their gender, the mother's education status (Erkan, 2011) and the socioeconomic level of the family (Erkan, 2011; Üstün, Akman, and Uyanık, 2000) are among the research findings.

There is an increase in research findings indicating that school readiness is associated with executive function performances (Blair \& Diamond, 2008; Graziano et al., 2016; Mann, Hund, Hesson-McInnis, and Roman, 2016; McClelland \& Wanless, 2012; Wenz-Gross, Yoo, Upshur, and Gambino, 2018). Although defined in different ways, executive functions are interrelated cognitive skills that are necessary for an individual to consciously keep knowledge in mind and to control, combine, and resolve the conflict between stimulus and response options (Blair, 2016). Research findings are available to support the effect of executive function skills on school readiness (Fujisawa, Todo, and Ando, 2019; Mann Hund, Hesson-McInnis, and Roman, 2016; Wenz-Gross et al., 2018; Willoughby, Piper, Oyanga, and Merseth, 2019). In a study with 104 children (3-5 years old), Mann, et al., (2016) showed that working memory and inhibitory control predicted academic readiness.

From the research findings discussed above, it can be concluded that because executive functions control the skills that enable learning to occur (Diamond, 2012), they are associated with school success (Whitebread and Basilio, 2012) and early mathematics-reading skills (Becker et al., 2014; Passolunghia et al., 2015). Based on the effect of executive functions on school readiness and school success, the aim of this study is to investigate the relationship between the 5- and 6-year-old children's readiness levels for primary education and their performance in executive function tasks.

\section{Method}

A relational survey design is used to examine the relationship between 5- and 6-year-old children's readiness levels for primary education and their performance in executive function tasks (Karasar, 2011). Analysis of the study was performed using data obtained from 69 children for the Nine Box task, 66 for the Less is More task and 48 for the Day-Night task. Data were gathered using the Marmara School Readiness Test (MSRT) and executive functions performance tasks, which were Less is More, Nine Box and Day-Night Task. Data were analyzed by using Kendall's Tau-b Correlation technique and Mann-Whitney U test. 


\section{Results}

A low level positive relationship was found between Less is More (measures inhibitory skills) and Marmara SRT sub-dimension of drawing, Nine Box (measures working memory skills) and mathematics, drawing, labyrinth and total Marmara SRT score, and Day-Night task (measures both working memory and inhibitory skills) and mathematics, science and total Marmara SRT score.

The results of Mann-Whitney U test demonstrate that children who successfully completed the Less is More task had higher scores on the drawing sub-dimension than those who could not complete the task successfully. In the Nine Box task, children with high averages were found to have high mathematics, drawing and labyrinth scores. Children who successfully complete the Day-Night task performances have higher scores on the science, sound and labyrinth sub-dimensions than their counterparts. It was determined that children's total score on the Marmara SRT did not differ according to executive function performances.

\section{Conclusion and Discussion}

The findings of this study indicate that school readiness levels, which are determined by measuring the mathematics, science, sound, drawing and labyrinth subdimensions, are related to executive function performances. The findings show that children's mathematics, drawing and labyrinth scores were related with their performances in working memory tasks. Science, sound and labyrinth scores were associated with both working memory and inhibitory control tasks. Children whose scores were higher on working memory and inhibitory control tasks had high scores on the sub-dimensions of science, sound and labyrinth. Children's total scores in school readiness did not differ according to their executive function performances. The findings coincide with the findings of studies that emphasize the effect of executive functions on school readiness (Becker, McClelland, Loprinzi, and Trost, 2014; Passolunghia et al., 2015). Based on the findings stating that children's school readiness levels differ according to executive function performance, it is important to take steps to support the working memory and inhibitory control capacities of children in the preschool period. In-service trainings should be provided to help preschool education teachers increase their level of knowledge of executive function processes and to help integrate these processes into a preschool education program. 


\section{GİRIŞ}

Erken çocukluk tüm gelişim alanlarıyla ilgili becerilerin edinilmesi açısından kritik bir dönemdir. Çocukların öğrenmeye ve okuma yazmaya hazır olması için gerekli olan, örneğin bir duruma dikkatini odaklayabilme ve algıladıklarını hatırlayabilme gibi becerilerin temeli bu yıllarda atılmaktadır. O nedenle, edinilen bilişsel, dil, motor ve sosyal-duygusal beceriler çocukları bir sonraki eğitim basamağına hazırlaması ve okul başarısını etkilemesi açısından önem taşımaktadır.

Alan yazında, öğrenmeye hazır oluş olarak tanımlanan okula hazır oluşun (Oktay, 2013) çocuğun yanında öğretmen ve okul ile ilgili nitelikleri de içine alarak geniş bir perspektifle tanımlanması gerektiği vurgulanmaktadır (Maxwell, Bryant, Ridley ve Keyes-Elstein, 2001; NAEYC, 2009). Çocuk açısından okula hazır oluş, sağlık-fiziksel gelişim, sosyal-duygusal gelişim, öğrenmeye yaklaşım, dil gelişimi ve biliş-genel bilgi şeklindeki gelişim ve öğrenme durumu olarak tanımlanmaktadır (Maxwell ve diğ., 2001).

Morrison’a göre de (2006) öğrenmeye ve okula hazır olunması için dil, bağımsızlık, dürtü kontrolü, kişilerarası beceriler, deneyimler, fiziksel ve zihinsel sağlık önem taşımaktadır. Önemli dil becerilerinin alıcı, ifade edici ve sembolik dil olduğu düşünülmektedir. Bunların yanında okumaya hazırlık ile ilgili olan harfleri tanıma, adlandırma ve ses farkındalığı da önemlidir. Bağımsızlık; tek başına çalışabilme, birisi ne ve nasıl yapması gerektiğini söylemeden bir çalışmayı başlatabilme, tuvalet, giyinme ve yeme gibi ihtiyaçlarını karşılayabilme becerilerini içermektedir. Dürtü kontrolü; diğerleriyle işbirliği içinde çalışabilme, onların çalışmalarına müdahale etmeme, belli bir süre öğrenme etkinliklerine katılabilmeyi sağlayıcı dikkat süresini geliştirme ve bir süre hareket etmeden durabilme ile ilgilidir. Kişilerarası beceriler; akranlarılla ve yetişkinlerle geçinebilme ve çalışabilmeyle ilişkilidir. Deneyimler; bilişsel gelişimin işlenmemiş materyalleri ve bilginin inşa edici yap1 taşları olmasından dolayı hazır oluş için önemlidir. Fiziksel ve zihinsel sağlık; çocukların herhangi bir programa tam olarak katılmalarını mümkün kılan olumlu beslenme, zihinsel ve fiziksel alıskanlıklara sahip olmaları gerekmektedir.

Öğretmen ve okul ile ilgili nitelikler de okula hazır oluşu etkilemektedir. Tüm çocukların başarılı olabilmeleri için onların farklı şekilde ve hızda geliştiklerinin dikkate alınması, farklı gelişim alanlarının desteklenmesi, ailelerin, toplumun, erken bakım-eğitiminin ve okulların hazır olması gerekmektedir. Evrensel olarak okul hazırllğını desteklemek için ise okul başarısını olumlu yönde etkileyen firsatlara tüm çocukların ulaşması, çocukların bireysel farklılıklarının belirlenmesi, desteklenmesi ve okula başladıklarında çocukların ulaşabileceği uygun beklentilerin saptanması önerilmektedir (NAEYC, 2009). Maxwell ve diğ., (2001), okulların tüm çocukları eğitme 
kapasitesine sahip olması gerektiğini belirtmektedirler. Dolayısıyla, öğretmen ve okulların okula hazır oluşu desteklemeleri için çocukların gelişimine bütünsel olarak yaklaşmaları ve öğrenme hızı gibi bireysel farklılıkları dikkate almaları gerektiği vurgulanmaktadır.

Çocukların okula hazır oluşunu etkileyen değişkenleri inceleyen araştırmalar farklı değişkenler üzerinde durmuşlardır. Oktay’a göre (1983), çocukların okula hazır oluşlarını etkileyen faktörler genellikle; fizyolojik, bilişsel, çevresel ve duygusal olarak sınıflandırılmaktadır. Çocukların okul öncesi eğitim alıp almama durumu, cinsiyeti, anne öğrenim durumu (Erkan, 2011) ve ailenin sosyoekonomik düzeyinin (Erkan, 2011; Üstün, Akman ve Uyanık, 2000) etkili olduğu araştırma bulguları arasındadır. Dinehart ve Manfra (2013), düşük sosyo-ekonomik seviyeden gelen okul öncesi dönem çocukların ince motor becerilerinin ikinci sınıf matematik ve okuma başarılarında etkisinin olduğunu saptamışlardır. Beş-altı yaş çocuklarının bilişsel tempolarına göre okula hazır oluşlarının incelendiği bir çalışmada ise reflektif bilişsel tempoya sahip çocukların diğer çocuklara göre hazır oluş düzeylerinin daha yüksek olduğu saptanmıştır. Bu da, onların okula hazır oluş ile ilişkilendirilen becerileri öğrenmelerini kolaylaştırıcı bir rol oynadığını göstermektedir (Koçyiğit ve Kayılı, 2014). Son yıllarda söz konusu bu değişkenlerin yanında, öğrenmeyi ve başarılı olmayı etkilendiğinden dolayı (Singer ve Bashir, 1999) okula hazır oluş, yürütücü işlev becerileri ile ilişkilendirilmektedir (Fujisawa, Todo ve Ando, 2019; Wenz-Gross ve diğ., 2018).

\section{Yürütücü İşlevler}

Farklı şekillerde tanımlanmakla beraber, yürütücü işlevler bireyin bilinçli olarak bilgiyi akılda tutma, kontrol etme, birleştirme ve uyaran ile tepki seçenekleri arasındaki çelişkiyi çözmek için gerekli olan birbiriyle ilişkili bilişsel becerileridir (Blair, 2016). Bir başka tanıma göre, düşüncenin ve davranışların izlenmesi ve kontrol edilmesine yardımcı olan üst düzey düşünme, öz-düzenleyici ve bilişsel süreçleri ifade etmektedirler (Carlson, 2005). Yürütücü işlevler muhakeme, planlama, problem çözme ve yaşamı yönetmeye yardımcı olan düşünme becerileri şeklinde de tanımlanmaktadırlar (Blair, 2017).

Okula hazır oluş ve okul başarısında yürütücü işlevlerin rolü motivasyon ve girişim ile ilişkilidir. Özellikle küçük çocuklarda yürütücü işlev becerileri bilginin karmaşıklık düzeyinin uygunluğuna ve orta düzey stresin düzenlenmesi için gerekli olan desteğe bağlıdır. Bilginin karmaşık ve çevrenin çok stresli olduğu durumlarda yürütücü işlevler faaliyetini durdururken, bilgi çok basit olduğunda ve çevre ilgi çekici olmadığında ise yürütücü işlevler harekete geçememektedir (Blair ve Raver, 2015). Dolayısıyla, yürütücü işlev becerilerinin desteklenmesinde bilginin karmaşıklık düzeyini çocukların seviyesine göre ayarlamak ve destekleyici bir çevre sunmak anahtar unsurlardır. 
Yürütücü işlevler, dikkat, çalışma belleği ve engelleyici kontrol gibi bilişsel süreçleri içermektedir (Miyake, Friedman, Emerson, Witzki ve Howerter, 2000; Welsh, Pennington ve Groisser, 1991). Diğer bir ifadeyle yürütücü işlevler, çalışma belleğinde bilgiyi tutmayı, uyarana yönelik otomatik tepkileri engellemeyi ve bir çalışmanın ilişkili fakat farklı boyutlar arasında dikkat odağını değiştirmeyi sağlayan bilişsel becerilerdir (Blair, 2017). Dikkat/Bilişsel esneklik, çalışma belleği ve engelleyici kontrolün birbirinden ayrı fakat tamamıyla bağımsız olmadıkları belirtilmektedir.

Dikkat/Bilisssel esneklik: Perspektif değiştirebilme becerisidir, bir problem hakkinda düşünüleni değiştirme ve değişen önceliklere ya da taleplere uyum sağlayabilme, yanlış olduğunu kabul etme ve beklenmedik firsatlardan yararlanabilme şeklinde tanımlanmaktadır (Diamond, 2012).

Çalı̧sma belleği: Bilgiyi akılda tutmayı ve zihinsel olarak işlemeyi içermektedir. Önceden gerçekleşen durumları şu anda gerçekleşenlerle ilişkilendirdiği için zaman içinde ortaya çıkan durumlara anlam vermek için önemlidir. Bu yüzden çalışma belleği duyulan ya da okunan bilgilere anlam vermek için gereklidir. Ayrıca, olayları tekrar düzenlemek, neden sonucu anlamak, genel bir ilke çıkarımı yapabilmek, zihinsel olarak parçaları ilişkilendirmek ya da eski düşünceler arasında yeni ilişkileri saptayabilmek ile ilgidir (Diamond, 2012).

Engelleyici kontrol: Otomatik bir tepkiyi bilinçli olarak engellemektir (Miyake ve diğ., 2000). Engelleme bireyin davranışlarını kontrol etmek için öz kontrol (İlk akla geleni söyleme isteğine karşı koyma gibi), disiplin uygulama (Bir görevi tamamlamama isteğine karşı koyma gibi) ve dikkati kontrol etme (Seçici ve odaklı) ile ilgilidir (Diamond, 2012).

Engelleyici kontrol yürütücü işlevlerin birleşmelerinde rol oynamaktadır. Diğer bir ifadeyle, tüm yürütücü işlevlerin uygun bir şekilde faaliyette bulunması için belli bir oranda engelleyici kontrol içerdiği belirtilmektedir (Miyake ve diğ., 2000). Engelleyici kontrol görevleri çalışma belleğini içerme düzeyine bağlı olarak basit ve karmaşık engelleyici kontrol süreçleri şeklinde ikiye ayrılır (Garon, Bryson ve Smith, 2008). Basit engelleyici kontrol en az düzeyde çalışma belleğini içermektedir. Bebeklerin bir şeyi yemekten vazgeçmeleri basit engelleyici kontrolün en erken gözlemlenen şeklidir. Karmaşı engelleyici kontrol, keyfi bir kuralı akılda tutmayı ve/veya bir tepkiyi engellemeyi ve alternatif bir tepki üretmeyi gerektirdiği için yüksek düzeyde çalışma belleğinin kullanımı gerektirir.

Alan yazında yürütücü işlev becerilerini ölçmek için Doyumu Erteleme (Mischel, Shoda ve Rodriguez, 1989) ve Gündüz-Gece (Gerstadt, Hong ve Diamond, 1994) gibi çeşitli performans görevleri geliştirilmiştir. Örneğin, Gündüz-Gece performansı yürütücü işlev görevleri arasında yer 
alan çalışma belleği ve engelleyici kontrol ile ilişkilidir (Diamond, Prevor, Callender ve Druin, 1997). Bu performansta çocuğun baskın olan sözel tepkiyi engellemesi (Örneğin, güneşin olduğu resme bakıp "Gündüz” demeyi) ve alternatif bir sözel tepkiyi harekete geçirmesi (Örneğin; güneş resminin olduğu resme bakıp "Gece” demesi) beklenmektedir (Gerstadt, Hong ve Diamond, 1994, akt.. Best ve Miller, 2010).

Okul öncesi çocukları için geliştirilen yürütücü işlev görevlerinin belli özellikleri taşıması gerekmektedir. Bu dönem çocuklarının dikkat sürelerindeki, dil yeterliliklerindeki ve genel bilgi ile ilgili ön deneyimlerindeki çeşitlilikten dolayı karmaşık sözel ve motor tepkilerin ve öğrenilecek kuralların en aza indirgenmesi gerektiği vurgulanmaktadır. Ayrıca, farklı kesimlerden gelen çocukların belirlenen yaşa kadar edindiği temel kavramlarla ilgili olması gerektiği belirtilmektedir (Wiebe ve diğ., 2011). Geliştirilen performans görevleri farklı yürütücü işlev alt boyutlarından birini (Engelleyici kontrol: Hediye Erteleme) ya da ikisini birden (Engelleyici kontrol ve çalışma belleği: Çimen-Kar) ölçmeye yönelik olabilmektedir. Hem engelleyici kontrol hem de çalışma belleğini içeren görevlerin daha zor olduğu belirtilmektedir (Carlson, 2005).

\section{Yürütücü İşlevler ve İlkokula Hazır Oluş}

Yürütücü işlevler ile öz-düzenleme süreçleri okulda öğrenme ve başarının temeli olan bilişsel, dil, davranışsal ve duygusal kontrol için esas teşkil etmektedir (Singer ve Bashir, 1999). Yürütücü işlevler çocukların okul ortamında davranışlarını kontrol etmelerine, yönergeleri hatırlamalarına, dikkat etmelerine ve öğrenme görevlerini tamamlamalarını sağlamaktadır (Aarnoudse-Moens ve diğ., 2009; McClelland ve diğ., 2014).

Yürütücü işlev becerilerinin okula hazır oluş üzerindeki etkisini destekler nitelikte araştırma bulgular1 mevcuttur (Fujisawa, Todo ve Ando, 2019; Mann Hund, Hesson-McInnis ve Roman, 2016; Wenz-Gross ve diğ., 2018; Willoughby, Piper, Oyanga ve Merseth, 2019). Mann, ve diğ., (2016) 3-5 yaş aralığındaki 104 çocukla yaptıkları araştırmada, çalısma belleği ve engelleyici kontrolün akademik hazırlığı yordadığını belirlemişlerdir. Bir başka araştırmada, anasınıfina başarılı bir şekilde geçiş yapan çocukların sınıfta davranışlarını ve dikkat gerektiren çalışmaları kontrol etmek için yürütücü işlevleri etkili bir şekilde kullandıkları saptanmıştır (Graziano ve dĭğ., 2016). Boylamsal bir çalışmada Ribner, Willoughby ve Blair (2017), 1292 çocukla akademik becerilerin gelişimine yürütücü işlevlerin katkısını incelemişlerdir. Bulgular, çocukların beş yaşındaki yürütücü işlev düzeylerinin beşinci sınıftaki akademik becerileri öngördüğü yönündedir. Yürütücü işlev becerilerinin erken matematik becerileriyle ilişki olduğu fakat okuma becerileriyle ilişkili olmadığ 
ve dolayısıyla yüksek yürütücü işlev becerilerinin okula başlamadan önce sınırlı akademik bilgiyi bir dereceye kadar telafi edebileceği belirtilmiştir.

McClelland ve diğ., (2014) davranışsal öz-düzenlemenin, bilişsel esnekliğin ve engelleyici kontrolün çocukların erken okuryazarlık, matematik ve kelime gelişimlerini yordadığını saptamışlardır. Ayrıca, öz-düzenleme ve yürütücü işlev becerilerinde gelişme olan çocukların en çok matematik becerilerinde ilerleme olduğunu belirlemişlerdir. Erken okuryazarlık becerileri ile karşılaştırıldığında, öz-düzenleme ve yürütücü işlevlerin en güçlü ve tutarlı bir şekilde matematik becerileri ve kelime ile ilişkili olduğu ortaya çıkmıştır. Matematik ile ilgili olarak, ordinal ve kardinal say1 kuralını kullanma, geçiş ve örüntüler çocukların esnek bir şekilde dikkatlerini problemin kısımları arasında değiştirmeleri ve verilen nesnenin bir özelliğini bir başka özellik için engellemelerini gerektirmektedir (Blair ve Raver, 2015). Bir araştırmada, çocukların anaokulunda genel bilişsel süreçleri (çalışma belleği ve dikkat kontrolü) ile filizlenen okuryazarlık ve aritmetik becerileri arasındaki ilişki ve bu bilişsel süreçlerin anasınıfında okuma ve matematik başarısına katkısı incelenmiştir. Bulgular, anaokulu yıllarındaki çalışma belleği ve dikkatin anasınıfındaki filizlenen okuryazarlık ve aritmetik becerilerinin gelişimini yordadığı yönündedir. Ek olarak, erken filizlenen aritmetik becerilerinin ileriki yürütücü işlevleri öngördüğü aynı zamanda erken yürütücü işlevlerin de erken filizlenen aritmetik becerilerini öngördüğü saptanmıştır (Welsh, Nix, Blair, Bierman ve Nelson, 2010).

Başka bir çalışma ise, eğitim öğretim yılının başında ve sonunda 100 çocuğun zeka, fonolojik becerileri, sayma, sözel ve görsel-uzamsal kısa süreli bellek ve çalışma belleği, hız ve sayı becerilerini değerlendirmiştir. Bulgular, eğitim öğretim yılı erken ve yılsonu sayı becerileri, fonolojik becerileri, sözel ve sözel olmayan zeka ile çalışma belleği arasında bir ilişki olduğunu göstermiştir (Passolunghia, Lanfranchib, Altoèb ve Sollazzoa, 2015). Blair ve Razza (2007), 3 ve 5 yaş çocuklarının çaba gerektiren kontrol, yürütücü işlev ve yanlış inanç anlamanın erken okuryazarlık ve matematik ilişkisini incelemişlerdir. Bulgular, yürütücü işlevlerin engelleyici kontrol boyutunun hem erken matematik hem de okuma becerileriyle ilişkili olduğunu göstermiştir.

Yukarıda tartışlan araştırma bulgularından, yürütücü işlevlerin öğrenmenin gerçekleşmesini sağlayan becerileri kontrol etmesinden dolayı (Diamond, 2012) okul başarısı (Mann, Hund, HessonMcInnis ve Roman, 2016; Whitebread ve Basilio, 2012) ve erken matematik-okuma becerileri ile ilişkili olduğu anlaşılmaktadır (Becker, McClelland, Loprinzi ve Trost, 2014; Passolunghia ve diğ., 2015). Bu nedenle, etkili yürütücü işlevler tarafından desteklenen üstbiliş ve öz-düzenleme becerileri hem genel hem de akademik gelişimde önemli bir role sahiptir (Whitebread ve Basilio, 2012). 
Yürütücü işlevlerin okula hazır oluş ve okul başarısı üzerindeki etkisinden hareketle bu çalışmada, 5-6 yaş çocuklarının okula hazır oluş düzeyleri ile yürütücü işlev görevlerinde sergiledikleri performansları arasındaki ilişki incelenmiştir.

\section{YÖNTEM}

5-6 yaş çocuklarının okula hazır oluş düzeyleri ile yürütücü işlev görevlerinde sergiledikleri performansları arasındaki ilişkiyi inceleyen bu araştırmada ilişkisel tarama yöntemi kullanılmıstır (Karasar, 2011).

\section{Çalışma Grubu}

Amaca uygun örneklem türü kullanılarak oluşturulan çalısma grubu Türkiye'nin bir güneybatı ilindeki iki anaokulu ve bir ilkokulun bünyesindeki anasınıflarına devam eden 5 -6 yaş çocuklarından oluşmaktadır. Pilot çalışma 25 çocukla yürütülmüştür. Uç değerlere sahip ve kayıp veriler çıkarıldıktan sonra asıl çalışmanın analizleri Dokuz Kutu görevi için 69 ve Az Olan Çok görevi için 66 çocuktan elde edilen veriyle gerçekleştirilmiştir. Gündüz-Gece görevinde eğitim aşamasını geçemeyen ve son yönerge tekrarından sonra da iki resimden birine yanlış cevap verilmesi durumunda uygulama sonlandırıldığı için veriler 48 çocuktan elde edilmiştir. Katılımcılarla ilgili betimleyici istatistikler Tablo 1'de verilmiştir.

Tablo 1. Çalışma grubu ile ilgili betimleyici istatistikler

\begin{tabular}{lll}
\hline Sosyo-demografik özellikler & Frekans & Yüzde \\
\hline Yaş Grubu ( $\bar{X}=70.98)$ & & \\
5 Yaş & 39 & 56.5 \\
6 Yaş & 30 & 43.5 \\
Cinsiyet & 35 & 50.7 \\
Kiz & 34 & 49.3 \\
Erkek & & 30.4 \\
Okul Öncesi Ë̆itime Devam Yulı & 21 & 69.6 \\
İlk yll & 48 & 27.5 \\
İkinci ve + & 19 & 37.7 \\
Anne Öğrenim Durumu & 26 & 34.8 \\
İlkokul ve ortaokul & 24 & 23.2 \\
Lise & & 37.7 \\
Önlisans/ Lisans ve üstü & 16 & 36.2 \\
Baba Öğrenim Durumu & 26 & \\
İlkokul ve ortaokul & 25 & 66.7 \\
Lise & & 33.3 \\
Lisans ve üstü & 46 & \\
Aile Gelir Durumu & 23 & \\
Ortalama altı $(\bar{X}=3128$ TL) & & \\
Ortalama üstü & & \\
\hline
\end{tabular}


Çocukların yaş ortalaması 70 ay $(\mathrm{SS}=4.64), 35$ ’ (50.7\%) kız ve 34’ü (49.3\%) erkektir. Aile gelirlerinin ortalaması alınarak aileler ortalama altı ve üstü olmak üzere iki gruba ayrılmıştır. Ailelerin 46’s1 (66.7\%) ortalama alt1 ve 23’ü (33.3\%) ortalama üstü gelire sahiptirler. Annelerin 24’ü (34.8 \%) önlisans, lisans ve üstü mezunuyken babaların ise 25 'inin (36.2\%) lisans ve üstü mezunu oldukları görülmektedir.

\section{Veri Toplama Araçları}

Çalışmanın verileri Kişisel Bilgi Formu, Marmara İlköğretime Hazır Oluş Ölçeği ve yürütücü işlev performansı ile ilgili görevler aracılığıyla toplanmıştır. Ölçme araçları sessiz bir ortamda bireysel olarak uygulanmıştır.

\section{Kişisel Bilgi Formu}

Çalışma grubu çocuklarının cinsiyeti, yaşı, okul öncesi eğitime devam yılı, anne-baba öğrenim düzeyi ve ailelerinin gelir düzeyi ile ilgili maddelerden oluşmaktadır. Bu form çocuk bilgi formları incelenerek doldurulmuştur.

\section{Marmara İlköğretime Hazır Oluş Ölçĕgi - Marmara İHO (Polat Unutkan, 2003)}

Bu çalışmada, Marmara İHO' nun 74 sorudan ve 5 alt boyuttan oluşan uygulama formu kullanılmıştır: Matematik (Rakam tanıma, arttırma-eksiltme, setler -renk, şekil-, sıralama: 47 soru), fen (tümevarım, tümdengelim, problem çözme: 14 soru), ses (Aynı sesle başlayan kelimeler, kafiyeli kelimeler: 8 soru), çizgi ( $3 \mathrm{soru})$ ve labirent $(2 \mathrm{soru})$. Sorular, doğru cevaba 1 ve yanlış cevaba 0 puan verilerek puanlanmaktadır. Alınabilecek maksimum puanlar şu şekildedir: Matematik 47, fen 14, ses 8 , çizgi 3 , labirent 2 ve toplam puan 74 . Ölçeğin uygulama formu için test-tekrar test güvenirliği $\mathrm{r}=.93, \mathrm{p}<.01$ ve iç tutarlılık katsayısının (Cronbach Alpha) r=.93, p<.01 olduğu belirlenmiştir. Formun uygulanması yaklaşık olarak 25 dakika sürmektedir. Bu çalışmada, Marmara İHO’ un uygulayıcılar arası uyum Kappa değerinin .88 olduğu belirlenmiştir.

\section{Yürütücü İslev Görevleri}

Yürütücü işlev süreçleri çalışma belleği, dikkat esnekliği ve engelleyici kontrolden oluşmaktadır. $\mathrm{Bu}$ araştırmada ise sadece çalışma belleği, engelleyici kontrol ve hem çalışma belleğine hem de engelleyici kontrole yönelik olan görevler kullanılmıştır. Çocukların engelleyici kontrol becerilerini belirlemek için “Az Olan Çoktur”, çalışma belleği performanslarını belirlemek için "Dokuz Kutu” 
ve hem çalışma belleğini hem de engelleyici kontrolü içeren "Gündüz-Gece" görevleri kullanılmıştır.

Bu çalışmada, yürütücü işlev performans görevlerinin dil eşdeğerliliğini belirlemek için ölçme araçlarının uygulanış şekli ve süreci ile ilgili bilgiler her iki dile de hakim olan bir psikolog ve iki okul öncesi eğitimi alan uzmanı olmak üzere üç uzman tarafından incelenmiştir. Geri bildirimler çerçevesinde uygulama şekli ve sürecinin Türkçe karşılıkları saptanmıştır. Bir sonraki aşamada ölçme araçları asıl çalışmada yer almayan çocuklara uygulanmıştır. Araştırmada güvenirlik ölçütlerinden bağımsız uygulayıcılar arası uyum ve gözlemlerin zamana bağlı olarak tekrarlanabilirliğini belirlemek için üç hafta arayla test-tekrar test kullanılmıştır (Karasar, 2011).

Az Olan Çok Görevi (Less is More) (Carlson, Davis ve Leach, 2005). Bu görev, çocukların engelleyici kontrol becerilerini belirlemek için kullanılmaktadır. Az Olan Çok çocuklara iki kap (şeffaf kap) içine konulmuş az (iki şeker) ve çok sayıda (beş şeker) olan şekerler arasından seçim yapmasını isteyen ters ödül olasılığına dayalı olan bir çalışmadır. Her defasında çocuğun parmağıyla işaret ederek gösterdiği tepsideki şekerlerin uygulamada kullanılan kuklanın tepsisine konulacağ1, diğer kaptaki şekerlerin de çocuğun tepsisine konulacağı anlatılır. Bu uygulamadaki kural çocuğun gösterdiği tepsideki şekerleri kuklanın alacağını hatırlamasıdır. Bu kuralın en fazla üç kez tekrarından sonra 16 kez bu uygulama gerçekleştirilir. Her uygulamadan sonra uygulayıcı kapları tekrar doldurur bir önceki uygulamada sağ tarafta olan kap sol tarafa ve sol tarafta olan da sağ tarafa konulur. Sekizinci uygulamaya başlamadan önce çocuğun performansına bakılmaksızın bu sözel kural hatırlatılmaktadır. Çocukların doğru cevabı; az şeker olan tepsiyi kuklaya verdiği zaman; 1 puan ve çok şekerin olduğu tepsiyi kuklaya verdiği zaman da puanı 0 olarak bir çizelgeye kaydedilir. Çocuğun alacağı puan “az şeker tepsisini” seçtiği uygulamaların toplamıdır. Alınabilecek en yüksek puan 16'dır. Bu çalışmada, 'Az Olan Çok' görevinin test tekrar test güvenilirliği için uygulanan ölçümler arasında ( $(\mathrm{r}=.39)$ orta düzeyde bir ilişki olduğu ve uygulayıcılar arası uyum Kappa değerinin .99 olduğu saptanmıştır.

Dokuz Kutu Görevi (Nine Box) (Diamond, Prevor, Callender ve Druin, 1997). Çalışma belleğinin kullanımıyla ilgilidir. Çocukların farklı şekil ve renkte kapağı olan dokuz kutudan birinin içine konulan küçük çizgi film karakterini bulmaları istenmektedir. Çocukların her denemede sadece bir kutuyu açmaları gerekmektedir. Her denemeden sonra kutular bir paravanın arkasında karıştırılmakta ve 15 saniye beklenildikten sonra uygulamaya devam edilmektedir. Çocukların karakteri dokuz kez bulabilmesi için maksimum 20 kez deneme yapabilmektedirler. Uygulama, karakter dokuz kez bulunduğunda ya da ardışı beş kez bulunamadığında sonlandırılmaktadır. 
Çocuğun ardışık olarak elde ettiği en yüksek doğru cevap sayısı aldığı puan olarak kaydedilmektedir. En yüksek puan 9'dur. Bu çalışmada, 'Dokuz Kutu' görevinin test tekrar test güvenilirliği için uygulanan ölçümler arasında ( $(\mathrm{r}=.46)$ orta düzeyde bir ilişki olduğu ve uygulayıcılar arası uyum Kappa değerinin 100 olduğu saptanmıştır.

Gündüz-Gece Görevi (Day-Night) (Gerstadt, Hong ve Diamond, 1994). Çalışma belleği ve engelleyici kontrolün kullanımını içermektedir. Gündüz-Gece görevinin kart ve bilgisayar versiyonları bulunmaktadır. Bu araştırmada bilgisayar versiyonu kullanılmıştır (Presentation by Neurobehavioral Systems, Inc., Berkeley, CA, USA). Sekiz adet güneş resmi ve sekiz adet ay-yıldızlı resimlerinin bulunduğu çalışma; eğitim, alıştırma ve gerçek uygulama kısımlarından oluşmaktadır. Eğitim aşaması, önce çocuğun gündüz ve gece resmini ayırt etmesi ve sonrasında gündüz resmini 'gece' ve gece resmini de 'gündüz' şeklinde söylemeyi öğrenmesi için yapılmaktadır. Alıştırma kısmında çocuğun gündüz resmine 'gece' ve gece resmine 'gündüz' diyebilmesi için yapılmaktadır. Çocuğun üç tur alıştırma hakkı bulunmaktadır. Eğer çocuk alıştırma aşamasında art arda iki doğru cevap verdiyse gerçek uygulamaya geçilmektedir. Eğitim aşamasını geçemeyen ve son yönerge tekrarından sonra da iki resimden birine yanlış cevap verilmesi durumunda uygulama sonlandırılmaktadır. Uygulayıcı çocuğun verdiği cevapları Gece için N (Night), Gündüz için D (Day) ve geçersiz cevap verdiğinde (Gece ya da gündüz dışında başka bir kelime söylerse) 0’1 tuşlayarak kaydetmektedir. Çocukların verdiği cevaplar ve bu cevapların doğru olup olmadığı da program tarafından kaydedilmektedir. Ayrıca, ses kaydı yoluyla çocukların tepki süresi de hesaplanabilmektedir. Bu çalışmada, sadece doğru cevap sayısı analizlere dahil edilmiştir. En yüksek puan 16'dır. Bu çalışmada, 'Gündüz-Gece' görevinin test tekrar test güvenilirliği için uygulanan ölçümler arasında $(r=.90)$ yüksek düzeyde bir ilişki olduğu ve uygulayıcılar arası uyum Kappa değerinin .58 olduğu belirlenmiştir.

\section{Verilerin Toplanması ve Analizi}

Çalışma için il Milli Eğitim Müdürlüğü’nden izinler alındıktan sonra amaca uygun örnekleme yöntemiyle seçilen okulların müdürleriyle ve öğretmenleriyle görüşülmüş ve çalışma hakkında bilgi verilmiştir. Çalışmaya gönüllü olarak katılmak istedikleri belirlendikten sonra veri toplama süreci başlatılmıştır. Benzer şekilde, çocuklar da çalışmaya katılıp katılmamakta serbest oldukları konusunda bilgilendirilmiştir. Veriler, üçüncü sınıfta öğrenim gören dört gönüllü okul öncesi öğretmen adayı tarafından toplanmıştır. Ölçekleri uygulayan öğrencilere günde üç saat olmak üzere toplam üç gün ölçme araçlarının tanıtılması ve uygulama süreci gibi konularda eğitim verilmiştir. Araştırmada, betimsel istatistikler örneklemin demografik özelliklerini ve Marmara İHO ve 
yürütücü işlevler performans görevlerini tanımlamak amacıyla kullanılmıştır. Az Olan Çok ve Gündüz-Gece görevlerinde, 12 puan altı alanlar başarıyla tamamlayamayanlar ve 12 puan ve üstü alanlar ise başarıyla tamamlayanlar şeklinde gruplandırılarak analizlere dahil edilmişlerdir (Carlson, 2005). Dokuz kutu görevinde çocuklar ortalamaya göre iki gruba ayrılmışlardır. Verilerin dağılımı Kolmogorov-Smirnov testi ile incelenmiştir. Veriler normal dağılım göstermediği için çocukların Marmara IHO ile yürütücü işlevler puanları arasındaki ilişki Kendall's tau-b korelasyon tekniği ve Mann-Whitney U testi kullanılarak incelenmiştir (Büyüköztürk, 2009).

\section{BULGULAR}

Çocukların okula hazır oluş düzeyleri ile yürütücü işlev performansları arasındaki ilişkiyi inceleyen bu araştırmanın değişkenleriyle ilgili betimsel istatistikler Tablo 2'de sunulmuştur.

Tablo 2. Marmara İHO ve yürütücü işlev görevlerine ilişkin betimleyici istatistikler $(\mathrm{N}=69)$

\begin{tabular}{lcc}
\hline & $\bar{X}$ & SS \\
\hline Marmara İlköğretime Hazır Oluş Testi & & 8.94 \\
Matematik & 34.01 & 2.03 \\
Fen & 8.92 & 2.00 \\
Ses & 3.91 & .304 \\
Çizgi & .101 & .734 \\
Labirent & .594 & 11.06 \\
Marmara İHO Toplam & 47.55 & Yüzde (\%) \\
Yürütücü İşlev Görevleri & Sayz (N) & 50.0 \\
Az Olan Çok Görevi & & 50.0 \\
Başarıly tamamlayamayan (12 altında puan alan) & 33 & 62.3 \\
Başariyla tamamlayan & 33 & 37.7 \\
Dokuz Kutu Görevi & & 18.8 \\
Ortalama altı & 43 & 81.3 \\
Ortalama üstü & 26 & \\
Gündüz-Gece Görevi & & \\
Başarıla tamamlayamayan (12 altında puan alan) & 39 & \\
Başarıly tamamlayan & &
\end{tabular}

Marmara İHO testinin alt boyutlarının en yüksek puanları Matematik 47, Fen 14, Ses 8, Çizgi 3, Labirent 2 ve toplamın 74 puan olduğu düşünüldügünde Tablo 2'ye göre, çocukların matematik, fen ve ses alt boyutlarında ortalama puanlarının yüksek olduğu, ancak çizgi ve labirent alt boyutları ve toplam ortalama puanlarının düşük olduğu söylenebilir. Yürütücü işlev görevlerinden alınabilecek en yüksek puanlar Az Olan Çok 16, Dokuz Kutu 9 ve Gündüz-Gece görevinde 16'dır. Az Olan Çok görevinde 12 puan üstü alanlar ve alamayanların eşit olduğu, Gündüz-Gece görevinde ise 12 puan üstü alanların çoğunlukta olduğu görülmektedir. Dokuz Kutu görevinde ise çocukların yaklaşık olarak yarısından fazlası ortalama altı puan almışlardır. 
Marmara İHO puanları ile yürütücü işlev görevleri arasındaki ilişki Kendall's tau-b korelasyon tekniği ile incelenmiş ve bulgular Tablo 4'te sunulmuştur.

Tablo 4. Marmara İHO ve Yürütücü İşlev Görevleri Puanları Arasındaki İlişkiye Yönelik Kendall’s Tau-B Korelasyon Analizi Sonuçları

\begin{tabular}{|c|c|c|c|c|c|c|c|c|c|c|}
\hline & & 1 & 2 & 3 & 4 & 5 & 6 & 7 & 8 & 9 \\
\hline \multirow[t]{7}{*}{ Marmara İHO } & 1.Matematik & - & & & & & & & & \\
\hline & 2.Fen & $.322 * *$ & - & & & & & & & \\
\hline & 3.Ses & .138 & $.233^{*}$ & - & & & & & & \\
\hline & 4.Çizgi & $.272^{* *}$ & .043 & .167 & - & & & & & \\
\hline & 5.Labirent & $.308^{* *}$ & $.202 *$ & .183 & .104 & - & & & & \\
\hline & 6.Marmara İHO & $.820 * *$ & $.469 * *$ & $.314^{* *}$ & $.296 * *$ & $.360 * *$ & - & & & \\
\hline & Toplam & & & & & & & & & \\
\hline Yürütücü İşlev & 7.Az Olan Çok & .085 & .130 & .075 & $.286^{*}$ & .025 & .133 & - & & \\
\hline \multirow[t]{2}{*}{ Görevleri } & 8.Dokuz Kutu & $.285^{* *}$ & .069 & -.066 & $.258^{*}$ & $.247^{*}$ & $.233^{* *}$ & .033 & - & \\
\hline & 9.Gündüz-Gece & $.220^{*}$ & $.248^{*}$ & .135 & -.046 & .198 & $.224^{*}$ & -.039 & .151 & \\
\hline
\end{tabular}

$* 0.05, * * 0.01$

Tablo 4 incelendiğinde, engelleyici kontrol becerilerine yönelik olan Az Olan Çok görevi ile Marmara İHO testinin çizgi alt boyutu arasında ve çalışma belleği performanslarını belirleyen Dokuz Kutu görevi ile matematik, çizgi, labirent ve toplam puanı arasında düşük düzeyde pozitif yönde bir ilişki saptanmıştır. Ayrıca, hem çalışma belleğini hem de engelleyici kontrolü içeren Gündüz-Gece görevi ile matematik, fen ve Marmara İHO toplam puanı arasında düşük düzeyde pozitif yönde bir ilişki bulunmaktadır.

Marmara İHO testinin alt boyutları ve toplam puanlarının yürütücü işlev görevleri değişkenine göre farklılaşıp farklılaşmadığını gösteren Mann Whitney U testi bulguları Tablo 5’te verilmiştir.

Tablo 5. Marmara İHO Testi ve yürütücü işlev görevleri arasındaki ilişkiye yönelik Mann Whitney U Testi sonuçları

\begin{tabular}{|c|c|c|c|c|c|c|}
\hline \multicolumn{2}{|c|}{ Marmara İHO Testi } & \multirow[t]{2}{*}{$\mathrm{N}$} & \multirow[t]{2}{*}{ Sira Ortalamasi } & \multirow[t]{2}{*}{ Sira Toplam1 } & \multirow[t]{2}{*}{$\mathrm{U}$} & \multirow[t]{2}{*}{$p$} \\
\hline Matematik & Az Olan Çok Görevi & & & & & \\
\hline & Başarıyla tamamlayamayan & 33 & 32.95 & 1087.50 & 526.50 & .8017 \\
\hline & Başariyla tamamlayan & 33 & 34.05 & 1123.50 & & \\
\hline & Dokuz Kutu Görevi & & & & & \\
\hline & Ortalama altı $(\bar{X}=6.04)$ & 43 & 31.28 & 1345.00 & 399.00 & $.047^{*}$ \\
\hline & Ortalama üstü & 26 & 41.15 & 1070.00 & & \\
\hline & Gündüz-Gece Görevi & & & & & \\
\hline & Başarıyla tamamlayamayan & 9 & 19.67 & 177.00 & 132.000 & .261 \\
\hline & Başarıyla tamamlayan & 39 & 25.62 & 999.00 & & \\
\hline \multirow[t]{10}{*}{ Fen } & Az Olan Çok Görevi & & & & & \\
\hline & Başarıyla tamamlayamayan & 33 & 30.00 & 990.00 & 429.00 & .134 \\
\hline & Başarıyla tamamlayan & 33 & 37.00 & 1221.00 & & \\
\hline & Dokuz Kutu Görevi & & & & & \\
\hline & Ortalama altı $(\bar{X}=6.04)$ & 43 & 37.16 & 1598.00 & 466.00 & .244 \\
\hline & Ortalama üstü & 26 & 31.42 & 817.00 & & \\
\hline & Gündüz-Gece Görevi & & & & & \\
\hline & Başarıyla tamamlayamayan & 9 & 12.89 & 116.00 & 71.000 & $.005^{*}$ \\
\hline & Başariyla tamamlayan & 39 & 27.18 & 1060.00 & & \\
\hline & Az Olan Çok Görevi & & & & & \\
\hline
\end{tabular}




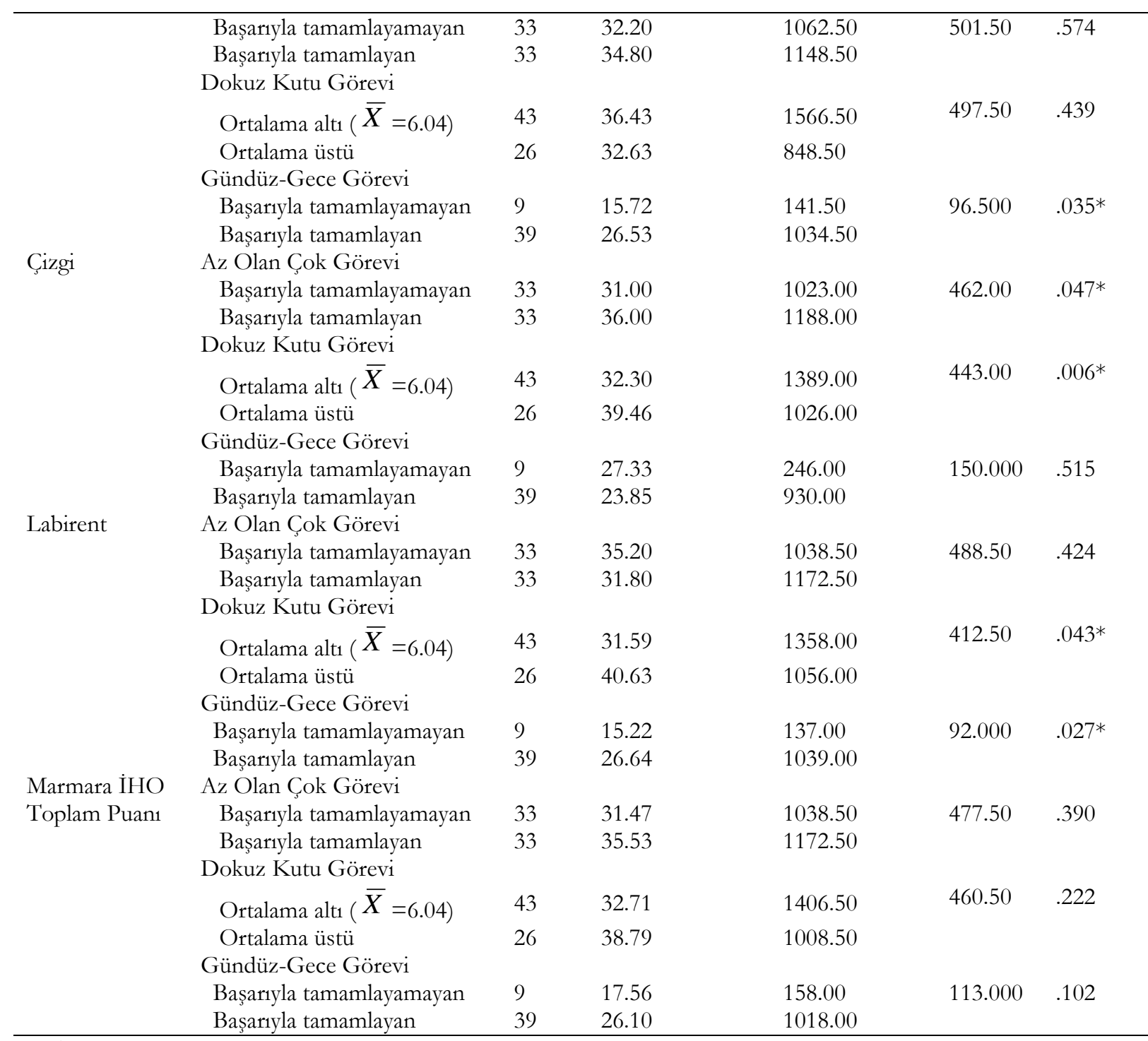

$* 0.05$

Tablo 5’e göre, çocukların Marmara İHO ölçeği çizgi alt boyutundan aldıkları puanları Az Olan Çok görevini başarıyla tamamlayıp tamamlamamaları değişkenine göre istatistiksel olarak anlamlı bir şekilde farklılaşmaktadır. Gruplar arasında, başarıyla tamamlayan grup lehine istatistiksel olarak anlamlı bir farklılık saptanmıştır. Çocukların matematik, çizgi ve labirent alt boyutlarından aldıkları puanların, Dokuz Kutu görev puanlarının ortalama altı olup olmaması değişkenine göre istatistiksel olarak anlamlı bir şekilde farklılaştı̆̆1 görülmektedir. Gruplar arasında, Dokuz Kutu görev puanlarının ortalama üstü olan grup lehine istatistiksel olarak anlamlı bir farklılık belirlenmiştir. Çocukların fen, ses ve labirent alt boyutlarından aldıkları puanları Gündüz-Gece görevini başarıyla tamamlayıp tamamlamamaları değişkenine göre istatistiksel olarak anlamlı bir şekilde farklılaşmaktadır. Gruplar arasında, başarıyla tamamlayan grup lehine istatistiksel olarak anlamlı bir farklılık saptanmıştır. Çocukların Marmara İHO testi toplam puanlarının ise yürütücü işlev görev performanslarına göre farklılaşmadığı belirlenmiştir. 


\section{SONUÇ ve TARTIŞMA}

$\mathrm{Bu}$ araştırmanın bulguları, çocukların matematik, fen, ses, çizgi ve labirent alt boyutlarının ölçülmesiyle belirlenen okula hazır oluş düzeylerinin yürütücü işlev performanslarıyla ilişkili olduğunu göstermektedir. Araştırmanın birinci bulgusu, Az Olan Çok görevini başarıyla tamamlayan çocukların tamamlayamayanlara göre çizgi alt boyutu puanlarının daha yüksek olduğunu yönündedir. Bu bulgu, yürütücü işlevlerin okula hazır oluş üzerindeki etkisini vurgulayan çalışmaların bulgularıyla örtüşmektedir (Becker ve diğ., 2014; Fujisawa, Todo ve Ando, 2019; Passolunghia ve diğ., 2015). Otomatik bir tepkiyi engellemeyi ve dikkati kontrol etmeyi gerektiren engelleyici kontrol performansları yüksek olan çocukların verilen yönergeleri anlayabildiği ve dikkate alabildikleri ileri sürülmektedir (Singer ve Bashir, 1999). Bu çalışmada engelleyici kontrolü ölçen Az Olan Çok görevi ile elini kaldırmadan noktaları birleştirme gibi nesne kullanımı ve el-göz koordinasyonuyla ilgili olan çizgi çalışmalarının ilişkili bulunması bu tür çalışmaların dikkatin kontrolünü gerektiren yönü olduğunu göstermektedir.

Araştırmanın ikinci bulgusu çocukların matematik, çizgi ve labirent alt boyut puanlarının onların Dokuz Kutu görevinde sergiledikleri performanslarıyla ilişkili olduğunu göstermektedir. Dokuz Kutu görevinde sıra ortalamaları yüksek olan çocukların düşük olanlara göre matematik, çizgi ve labirent puanlarının daha yüksek olduğu saptanmıştır. Bu bulgu, yürütücü işlevlerle okuryazarlık ve matematik becerileri arasındaki ilişkiyi inceleyen araştırmaların bulgularını destekler niteliktedir (McClelland ve diğ., 2014; Welsh ve diğ., 2010). Dokuz Kutu görevi çalışma belliğinin kullanımını gerektirmektedir. Çalışma belleği bilgiyi akılda tutma ve zihinsel olarak işleme ile ilgili ve duyulan ya da okunan bilgilere anlam vermek için gerekli olduğundan dolayı çocukların matematik, çizgi ve labirent puanlarıyla ilişkili olduğu düşünülmektedir. Örneğin, Marmara İHO ölçeği matematik alt boyutunda yer alan rakam tanıma, arttırma-eksiltme ve sıralama gibi sorulara çocukların doğru cevap verebilmesi için yönergeyi anlamlandırması ve zihinsel olarak işlemesi, diğer bir ifadeyle çalışma belleğinin kullanımını gerektirmektedir (Diamond, 2012). Bu açıdan yüksek çalışma belleği kapasitesinin çocukların matematik becerilerini öğrenmelerini kolaylaştırdığı söylenebilir.

Yürütücü işlevlerle matematik becerileri arsındaki ilişkinin tek yönlü olmadığı da vurgulanmaktadır. Bazı araştırmalar erken yürütücü işlevler ile matematik becerileri arasında karşılıklı bir ilişki olduğu yönünde önemli bir bulgu elde etmişlerdir (McClelland ve diğg., 2014; Welsh ve diğ., 2010). Farklı bir deyişle, okul öncesi dönemde erken yürütücü işlev becerilerinin gelişimi erken matematik becerilerinin gelişimini desteklediği gibi tersi de söz konusudur. 
Araştırmanın bir diğer bulgusu ise Gündüz-Gece görevi performanslarını başarıyla tamamlayan çocukların tamamlayamayanlara göre fen, ses ve labirent alt boyutu puanlarının daha yüksek olduğudur. Bu bulgu, alan yazında çalışma belleği ve engelleyici kontrol ile okula hazırlık becerileri arasındaki ilişkiye odaklanan araştırmaların bulgularıyla örtüşmektedir (Becker, McClelland, Loprinzi ve Trost, 2014; Blair ve Razza, 2007; Passolunghia ve diğ., 2015). Örneğin Blair ve Razza (2007), 3-5 yaş çocuklarıyla yaptıkları çalışmada engelleyici kontrolün hem erken matematik hem de okuma becerileriyle ilişkili olduğunu saptamışlardır. Gündüz-Gece görevi hem çalışma belleğini hem de karmaşık engelleyici kontrolün kullanımını içeren bir görevdir. Çocukların hem bilgiyi zihinde işlemelerini hem de otomatik tepkileri engelleme ve dikkatini kontrol edebilmelerini gerektirmektedir (Diamond, 2012). Gündüz-Gece görevi çocukların keyfi bir kuralı akılda tutmayı, otomatik tepkiyi engelleyip farklı bir tepki vermeyi gerektirdiğinden dolayı yüksek düzeyde çalışma belleğinin kullanımını, yani karmaşık engelleyici kontrolü içermektedir (Best ve Miller, 2010). Çocukların gerek Marmara İHO ölçeğinin fen alt boyutundaki problem çözme durumlarına çözüm üretebilmesi (Banyosunu su basan birinin bu durumdan nasıl kurtulabileceğine dair çözümler üretmesi), ses alt boyutundaki görseldeki nesne ile aynı sesle başlayan veya biten başka bir nesne ismi söylemesi ve gerekse labirent alt boyutunda elini kaldırmadan ve sınırı taşırmadan belirlenen hedefe ulaşması onların zihinsel olarak parçaları ilişkilendirebilme ya da önceki düşünceler arasında yeni ilişkileri saptayabilme kapasiteleri, diğer bir ifadeyle çalışma belleğini (Diamond, 2012) kullanmalarını gerektirmektedir. Ek olarak, otomatik tepkileri, örneğin, ses alt boyutunda aynı sesle biten yerine aynı sesle başlayan nesne ismini söylemeyi engelleme becerisi engelleyici kontrol ile ilişkilidir (Singer ve Bashir, 1999). Ling, Wong ve Diamond'a (2015) göre, Gündüz-Gece görevinde çocuklar için çalışma belleğini kullanmanın zor olmadığı ancak asıl zor olan kısmın baskın olan tepkiyi engellemek, diğer bir ifadeyle engelleyici kontrolü devreye sokabilmektir.

Erken yürütücü işlev becerilerinin gelişimi ile matematik becerilerinin gelişimi arasındaki karşıllklı bir ilişkinin olması (Welsh ve diğ., 2010) matematik becerilerinin desteklenmesinin yürütücü işlev becerilerinin gelişimine olumlu etki etmesi anlamına gelmektedir. Aynı zamanda, erken matematik becerileri düşük fakat yürütücü işlev becerileri yüksek olan çocukların, akademik becerileri yüksek olan çocukların başarısını yakalayabilecekleri vurgulanmıştır (Ribner ve diğ., 2017). Dolayısıyla, bu yöndeki bir etki de fen ve ses gibi diğer akademik becerilerin gelişimi açısından önem taşımaktadır. Bu durum, çocukların matematik becerilerinin hali hazırda var olan okul öncesi eğitimi programına ek olarak matematik programları aracıllğıyla desteklenmesi ihtiyacına işaret etmektedir. Yürütücü işlevlerin öğrenme ve başarıdaki etkisi dikkate alındığında (Becker ve diğg., 2014), bu becerilerin okula hazır oluşu destekleyici çalışmalara dahil edilmesinin gerekliliğini de ortaya koymaktadır. 
Sonuç olarak, okul öncesi dönem çocuklarının okula hazır oluş alt boyutlarına ait düzeyleri onların yürütücü işlev performanslarına göre farklılaşmakla beraber okula hazır oluş toplam puanına göre farklılaşmamaktadır. Çocukların matematik, çizgi ve labirent becerileri çalışma belleği performansına, fen, ses ve labirent puanlarının ise hem çalışma belleği hem de engelleyici kontrol performanslılarına göre değişiklik göstermektedir. Çalışma belleği performansı yüksek olan çocukların matematik, çizgi ve labirent alt boyutu puanlarının, hem çalışma belleği hem de engelleyici kontrol performansları yüksek olan çocukların ise fen, ses ve labirent alt boyutlarından aldıkları puanlarının yüksek olduğu görülmektedir.

Bu araştırmanın, çalışma belleği ve engelleyici kontrol becerilerinin matematik ve fen gibi becerilerle ilişkili olduğuna dair önemli bulguları olmasıyla birlikte sınırlılıkları da mevcuttur. Sınırllıkların ilki, yürütücü işlevlerin okula hazır oluş üzerindeki rolünün belirlenmesinde sadece çalışma belleği ve engelleyici kontrol süreçleri ile ilgili görevler kullanılmıştır. Bu ilişkinin daha detaylı bir şekilde incelenmesi için yürütücü işlevlerin çalışma belleği ve engelleyici kontrol süreçlerinin yanında dikkat esnekliği boyutunu da ölçen görevler araştırmalara dahil edilebilir. Çalışmanın bir diğer sınırlılığı da her ne kadar Marmara İHO ölçeği matematik ve ses alt boyutlarını içerse de, çocukların matematik ve dil becerilerinin farklı boyutlarının değerlendirilememiş olmasıdır. Matematik ve dil becerilerinin farklı boyutları, örneğin geometrik şekiller ve alıcı-ifade edici dil becerileri ile yürütücü işlevler arasındaki ilişki ilişkisel tarama yöntemiyle veya yarı deneysel çalışmalar yoluyla daha derinlemesine incelenebilir.

Araştırmanın bulgularından hareketle okul öncesi dönemde çocuklarının çalışma belleği ve engelleyici kontrol becerilerinin desteklenmesine yönelik deneyimlere yer verilmesi önem taşımaktadır. Öğretmenlere, yürütücü işlev süreçleri hakkında ve bu süreçleri destekleyici uygulamaların okul öncesi eğitimi programıyla bütünleştirilmesine yönelik hizmet içi eğitimlerin sunulması gerekebilir. Ayrıca, 3-4 yaş gibi erken yaş gruplarının yürütücü işlev süreçlerinin incelenmesi de olası desteklenmesi gereken becerilerin erken tespit edilmesine ve ilgili müdahale programlarının hazırlanmasına yardımcı olacağı düşünülmektedir. Araştırmalar, yaş gruplarını çeşitlendirerek, yürütücü işlevlerin tüm süreçlerine yönelik görevler kullanarak, özellikle çocukların yürütücü işlev becerileri ile geometrik şekiller ve alıc1-ifade edici dil becerileri arasındaki ilişkiyi inceleyebilirler. 


\section{KAYNAKÇA}

Aarnoudse-Moens, C. S., Smidts, D. P., Oosterlaan, J., Duivenvoorden, H. J., \& Weisglas-Kuperus, N. (2009). Executive Function in Very Preterm Children at Early School Age. Journal Abnormal Child Psychology, 37, 981-993.

Becker, D. R., McClelland, M. M., Loprinzi, P., \& Trost, S. G. (2014). Physical activity, selfregulation, and early academic achievement in preschool children. Early Education and Development, 25, 56-70.

Best, J. R., \& Miller, P. H. (2010). A Developmental perspective on executive function. Child Development, 81(6), 1641-1660. DOI:10.1111/j.1467-8624.2010.01499.x.

Blair, C. (2016). The development of executive functions and self-regulation: A bidrectional psychobiological model(Bölüm 23,ss.417-440). Handbook of Self-Regulation: Research, Theory and Applications (Editörler: K. D. Vohs \& R. F. Baumeister), NY: The Guilford.

Blair, C. (2017). Educating executive function. WIREs Cognitive Science, 8, 1-6.e1403. DOI: $10.1002 /$ wcs. 1403

Blair, C., \& Diamond, A. (2008). Biological processes in prevention and intervention: The promotion of self-regulation as a means of preventing school failure. Development and Psychopathology, 20, 899-911.

Blair, C., \& Raver, C. C. (2015). School readiness and self-regulation: A developmental psychobiological approach. Annual Review of Psychology, 66, 711-731.

Blair, B., \& Razza, R. P. (2007). Relating effortful control, executive function, and false belief understanding to emerging math and literacy ability in kindergarten. Child Development, 78, 2, 647-663.

Büyüköztürk, Ş. (2009). Sosyal Bilimler için Veri Analizi El Kitabı İstatistik, Araștrma Deseni SPSS Uygulamalar ve Yorum. Ankara: PEGEM.

Carlson, S. M. (2005). Developmentally sensitive measures of executive function in preschool children. Developmental Neuropsychology, 28(2), 595-616, DOI: 10.1207/s15326942dn2802_3

Carlson, S. M., Davis, A. C., \& Leach, J. G. (2005). Less is more: Executive function and symbolic representation in preschool children. Psychological Science, 16, 609-616.

Diamond, A. (2012). Activities and programs that improve children's executive functions. Current Directions in Psychological Science, 21(5) 335 -341.

Diamond, A., Kirkham, N., \& Amso, D. (2002). Conditions under which young children can hold two rules in mind and inhibit a prepotent Respons. Developmental Psychology, 38(3), 352-362.

Diamond A., Prevor M.B., Callender G., \& Druin D. P. (1997). Prefrontal cortex cognitive deficits in children teated early and continuously for PKU. Monographs of the Society for Research in Child Development 62:1-206. [PubMed: 9353949] 
Dinehart, L., \& Manfra, L. (2013). Associations between low-1ncome children's fine motor skills in preschool and academic performance in second grade. Early Education and Development, 24, 138-161.

Erkan, S. (2011). Farklı sosyoekonomik düzeydeki ilköğretim birinci sınıf öğrencilerinin okula hazır bulunuşluklarının incelenmesi. Hacettepe Üniversitesi Eğitim Fakültesi Dergisi, 40: 186-197.

Fujisawa, K. K., Todo, N., \& Ando, J. (2019). Changes in genetic and environmental influences on cognitive ability, executive function, and preacademic skills in Japanese preschool age twins. Developmental Psychology, 55(1), 38-52.

Garon, N., Bryson, S. E., \& Smith, I. M. (2008). Executive function in preschoolers: A review using an integrative framework. Psychological Bulletin, 134,1, 31-60.

Gerstadt, C., Hong, Y., \& Diamond, A. (1994). The relationship between cognition and action: Performance of $3 \frac{1}{2}-7$ year old children on a stroop-likeday-night test. Cognition, 53, 129_ 153.

Graziano, P. A., Garb, L. R., Ros, R., Hart, K., \& Garcia, A. (2016). Executive functioning and school readiness among preschoolers with externalizing problems: The moderating role of the student-teacher relationship. Early Education and Development, 27,5, 573-589.

Karasar, N. (2011). Bilimsel Araștırma Yöntemi: Kavramlar İlkeler Teknikler. Ankara: Nobel.

Koçyiğit, S., \& Kayılı, G. (2014). Farklı bilişsel tempoya sahip anaokulu çocuklarının ilkokula hazır bulunuşluklarının incelenmesi. Eğitim ve Bilim, 39, 175, 14-26.

Ling, D.S., Wong, C. D., \& Diamond, A. (2015). Do children need reminders on the Day-Night task, or simply some way to prevent them from responding too quickly? Cognitive Development, 37, 67-72.

Mann, T. D., Hund, A. M., Hesson-McInnis, M. S., \& Roman, Z. J. (2016). Pathways to school readiness: Executive functioning predicts academic and social-emotional aspects of school readiness. Mind, Brain, and Education, 11(1), 21-31.

Maxwell, K. L., Bryant, D. M., Ridley, S. M., \& Keyes-Elstein, L. (2001). North Carolina's kindergartners \& schools: Summary report. Chapel Hill: University of North Carolina, Frank Porter Graham Child Development Center.

McClelland, M. M., Cameron, C. E., Duncan, R., Bowles, R. P., Acock, A. C., Miao, A., \& Pratt, M. E. (2014). Predictors of early growth in academic achievement: The Head-Toes-KneesShoulders task. Frontiers in Psychology, 5, 1-14.

McClelland, M. M. \& Wanless, S. B. (2012) Growing up with assets and risks: The importance of self-regulation for academic achievement. Research in Human Development, 9, 4, 278-297.

Mischel, W., Shoda, Y., \& Rodriguez, M. L. (1989). Delay of gratification in children. Science, 244, 933-938. 
Miyake, A., Friedman, N. P., Emerson, M. J., Witzki, A. H., \& Howerter, A. (2000). The unity and diversity of executive functions and their contributions to complex "frontal lobe" tasks: A latent variable analysis. Cognitive Psychology, 41, 49-100.

Morrison, G. S. (2006). Foundations of Early Childhood Education. Ohio: Pearson Education Inc.

National Association for the Education of Young Children (NAEYC, 2009). Where we stand on School Readiness.

Oktay, A. (1983). Okul Olgunluğu. İstanbul Üniversitesi Edebiyat Fakültesi Yayınları No: 3089.

Oktay, A. (2013). Okul öncesi eğitim ve ilköğretimin çocuğun yaşamındaki yeri ve önemi (ss.1-23). Illkögretime Hąırllk ve Illkögretim Programlar. PEGEM.

Passolunghia, M. C., Lanfranchib, S., Altoèb, G., \& Sollazzoa, N. (2015). Early numerical abilities and cognitive skills in kindergarten children. Journal of Experimental Child Psychology, 135, 2542 .

Polat Unutkan, Ö. (2003). Marmara ilkögretime hazır olus ölçeğinin geliştirilmesi ve standardizasyonu (Development and standardization of Marmara primary school readiness scale). (Unpublished $\mathrm{PhD}$ Thesis), Marmara University, Education Sciences Institute, Istanbul.

Ribner, A. D., Willoughby, M. T., Blair, C. B., \& The Family Life Project Key Investigators (2017). Executive Function Buffers the Association between Early Math and Later Academic Skills. Frontiers in Psychology, 8. doi.org/10.3389/fpsyg.2017.00869

Singer, D. B., \& Bashir, A. S. (1999). What are executive functions and self-regulation and what do they have to do with language-learning disorders? Language, Speech, and Hearing Services in School, 30, 265-273.

Üstün, E., Akman, B., \& Uyanık, G. (2000). Farklı sosyoekonomik kökenli 6 yaş grubu çocukların ilkokula hazırlık düzeylerinin bir değerlendirmesi. Eğitim ve Bilim, 25, 116, 54-58.

Welsh, J. A., Nix, R. L., Blair, C., Bierman, K. L., \& Nelson, K. E. (2010). The development of cognitive skills and gains in academic school readiness for children from low-1ncome families. Journal Educational Psychology, 102(1), 43-53. DOI:10.1037/a0016738.

Welsh, M. C., Pennington, B. F., \& Groisser, D. B. (1991). A normative-developmental study of executive function: A window on prefrontal function in children. Developmental Neuropsychology, 7, 131-149.

Wenz-Gross, M., Yoo, Y., Upshur, C. C., \& Gambino, A. J. (2018). Pathways to kindergarten readiness: The roles of second step early learning curriculum and social emotional, executive functioning, preschool academic and task behavior skills. Frontiers in Psychology, 9, $1-19$.

Whitebread, D., \& Basilio, M. (2012). The emergence and early development of self-regulation in young children. Profesorado,16(1), 15-33. 
Wiebe, S. A., Sheffield, T., Nelson, J. M., Clark , C. A., Chevalier, N., \& Espy, K. A. (2011). The structure of executive function in 3-year-old children. Journal of Experimental Child Psychology. 108(3), 436-452.

Willoughby, M. T., Piper, B., Oyanga, A., \& Merseth, K. K. (2019). Measuring executive function skills in young children in Kenya: Associations with school readiness. Develepmental Science, 18:e12818. 